\title{
Rejuvenation and Adventitious Rooting in Coppice-Shoot Cuttings of Tectona grandis as Affected by Stock-Plant Etiolation
}

\author{
Azamal Husen \\ Department of Biology, Faculty of Natural and Computational Sciences, University of Gondar, Gondar, Ethiopia. \\ Email: adroot92@yahoo.co.in
}

Received February $8^{\text {th }}, 2011$; revised April 25 $5^{\text {th }}, 2011$; accepted July $5^{\text {th }}, 2011$.

\begin{abstract}
The effect of stock-plant etiolation on adventitious rooting of single-node leafy cuttings (SNCs) made from coppice shoots from different age groups of donor plants were investigated for teak (Tectona grandis Linn. $f$.). When donor plants age were 1-, 2-, 3-, 4-, and 5-year-old, they were coppiced and maintained in the dark for etiolation, while a parallel set was kept in normal light in an open environment. After 20 days, coppice shoots were made into SNCs which were cultured under intermittent mist for rooting. Stock-plant etiolation significantly increased percent rooting, shoot and root length, and number of roots per SNC, but callusing at the base of SNCs decreased. Etiolated SNCs have shown $71.7 \%$ rooting, whereas for controls (non-etiolated), the response was $41.7 \%$. The effect of aging on callusing, rooting and sprouting of etiolated and non-etiolated coppice shoots cuttings varied widely. Aging of donor plants decreased rooting and sprouting capability in SNCs and increased callusing at the base of etiolated cuttings. The results showed that stock-plant etiolation in 1-, 2-, 3-, 4-, and 5-year-old donor plants hastened rooting potential by rejuvenation of coppice shoots.
\end{abstract}

Keywords: Adventitious Rooting, Cuttings, Etiolation, Maturity, Tectona grandis

\section{Introduction}

Teak (Tectona grandis Linn. f.) is considered as the noblest among all woods not simply because of its golden hue and wonderful texture, but even more because of its durability. This species grows naturally in India, Myanmar, Laos and Thailand, and it is naturalized in Java, Indonesia, where it was probably introduced some 400 to 600 years ago [1]. In addition, it has been established throughout tropical Asia, as well as in tropical Africa (including Côte d'Ivoire, Nigeria, Sierra Leone, the United Republic of Tanzania and Togo), Latin America and the Caribbean (Costa Rica, Colombia, Ecuador, El Salvador, Panama, Trinidad and Tobago and Venezuela); and introduced in some islands in the Pacific region (Papua New Guinea, Fiji and the Solomon Islands) and in northern Australia at trial levels [1]. Generally, rootshoots/stumps and seeds are used as a planting material in teak plantations. The root-shoot/stumps are prepared by cutting one-year-old healthy seedlings into $15-0 \mathrm{~cm}$ root and $2.5 \mathrm{~cm}$ shoot portion with more than $1.0 \mathrm{~cm}$ thickness [2]. Quality teak stumps can be produced from seeds collected from identified best seed sources, such as seed production areas and seed orchards [2]. However, the seed yield per tree is low, and only few seedlings are produced per 100 seeds [3]. Therefore, propagation through cuttings has been widely used to multiply the elite teak trees obtained from the natural population to exploit the genetic variability [4]. Cutting loss of rooting potential with stock plant age/or maturation is studied for many forest tree species [5-8]. Attempts have been made to understand and improve the adventitious rooting efficiency of cuttings in selected plant species including teak because various intrinsic as well as extrinsic factors are responsible for adventitious root formation [9-17]. Among these factors, manipulation of stock plants via exposure to darkness for etiolation was used to improve the rooting status of stem cuttings. Reports have shown that stockplant etiolation increased adventitious root formation by a number of different taxa including teak [10,15,18-21]. Various anatomical, physiological and molecular changes were found to be associated with enhanced rooting efficiency in etiolated stem tissues [15,18-21]. To date, with reference to rooting of teak cuttings on the relationship 
between stock-plant etiolation and aging of donor plants is unknown. Therefore, the present study focuses on whether etiolation and maturation/or aging can affect on adventitious rooting capacity of coppice shoots singlenode leafy teak cuttings.

\section{Methodology}

\subsection{Experimental Site}

The experiments were conducted at the Plant Physiology nursery of New Forest campus, Forest Research Institute (FRI), Dehra Dun, India. The FRI campus is located in the Doon valley, and is surrounded by Western Lesser Himalayan ranges in the north and Shiwalik ranges in the south. This campus covers an area of $4.5 \mathrm{~km}^{2}$, and lies at an elevation of $640.08 \mathrm{~m}$ above mean sea level. It is situated on North Latitude $30^{\circ} 20^{\prime} 40^{\prime \prime}$ and East Longitude $77^{\circ} 52^{\prime} 12^{\prime \prime}$ on the northern limit of the Oriental region.

\subsection{Donor Plants and Stock-Plant Etiolation}

Regularly at different time intervals (1998-2003), the donor plants were raised in nursery beds using seeds collected from teak (clone FG1) seed orchard of New Forest campus, FRI. They were maintained by regular watering and weeding. Complete protection was provided against diseases and insects by foliar spray with insecticides and fungicides, as and when required. From these stock plants five aged group of donor plants were chosen, namely 1-, 2-, 3-, 4-, and 5-year-old. The seedlings in each age group donor plants were severed in June 2003, so that the stem retained only three basal nodes (i.e. stock plant), and they were divided into two groups. Coppicing was performed considering that stem will produce more coppice shoots. It is an established fact that coppicing resulted in cutting back the plants to more ontogenetically tissue, although the oldest teak seedlings were 5-year-old. Thereafter, the first group (1-, 2- 3-, 4-, and 5-year-old stock plants) was maintained under natural light (i.e., control) in an open environment, while the second group (1-, 2-, 3-, 4-, and 5-year-old stock plants) was kept in the dark for etiolation.

\subsection{Rooting Trials}

After 20 days, rooting trials were conducted using about $4.0 \mathrm{~cm}$ long leafy coppice shoots obtained from etiolated and non-etiolated stock plants of each age group. Coppice shoots were used for the preparation of single-node leafy cuttings (SNCs). SNCs used for this experimentation were obtained from the basal portion of coppice shoots. Coppice shoots obtained from etiolated and nonetiolated stock plants were divided into ten sub-groups of 50 SNCs each, and they were belonged to 1-, 2-, 3-, 4-, and 5-year-old donors. All SNCs were treated with $0.05 \%$ $(\mathrm{w} / \mathrm{v})$ bavistin for $30 \mathrm{~min}$. The cuttings were inserted into sterilized vermiculite $(\mathrm{pH}$ 7.0) pre-soaked in water for $24 \mathrm{~h}$. Then these leafy cuttings were cultured in the trays and incubated in a mist chamber. Automatic misting cycle was set at $60 \mathrm{~s}$ on and $1 \mathrm{~h}$ off duration in day, while during the night it was $30 \mathrm{~s}$ on and $1 \mathrm{~h}$ off duration. Inside the mist chamber, the RH was maintained at $85 \% \pm 2 \%$, and maximum and minimum day/night temperature were $32^{\circ} \mathrm{C} \pm 10^{\circ} \mathrm{C}$ and $26^{\circ} \mathrm{C} \pm 10^{\circ} \mathrm{C}$, respectively. After 50 days, the cuttings were carefully removed from the rooting medium, and observations were made on percent callusing, percent sprouting, percent rooting, number of shoots and their length $(\mathrm{cm})$, number of leaves per cutting, and number of roots per cutting and their length (cm).

\subsection{Statistical Analysis}

The experiment was conducted in a randomized block design, involving two light conditions (control, i.e., natural light and etiolation) and five aged groups of donor plants (1-, 2-, 3-, 4-, and 5-year-old). Five replications were used, with ten SNCs per replication. Prior to statistical analyses, all percent data were transformed into arc sin square roots and the data were analyzed by two-way analyses of variance. Comparisons between the mean values were made by the least significance difference (LSD test) at $P<0.05$. The SPSS/PC software Ver. 16.0 was used to process all the data.

\section{Results}

Results showed that stock-plant etiolation significantly decreased callusing at the base of SNCs. It was $20 \%$ for non-etiolated SNCs as compared to $6.7 \%$ of the etiolated cuttings (Table 1). Age of donor plants exhibited significant remarkable variation in the formation of callus in SNCs. Percent callusing was absent in coppice-shoot cuttings of 1-, 2-, 3-year-old donors. However, callusing of cuttings was $3.3 \%$ and $10 \%$ for $4-$, and 5-year-old donors, respectively (Table 2). Rooting percentage was higher for SNCs $(71.7 \%)$ obtained from etiolated stock plants than those from $(41.7 \%)$ non-etiolated stock plants. Mean root length and number of roots per SNC was also more in etiolated stock plants as compared to non-etiolated stock plants (Table 1). With increasing age of donor plants, rooting efficiency in terms percent rooting, mean root length and number of roots per SNC declined significantly. Highest $(78.2 \%)$ rooting percentage was recorded in 1-year-old donors, whereas it was lowest $(53.3 \%)$ in 5-year-old donors (Table 2). Stock-plant etiolation caused an increase in percent sprouting, $48.3 \%$ of the non-etiolated SNCs sprouted, as compared to $73.3 \%$ 
of the etiolated cuttings. Further etiolation significantly enhanced number of shoots and leaves per SNC, and mean shoot length per SNC (Table 1). However, aging of donor plants caused a significant decrease in percent sprouting. SNCs obtained from 1-year-old donors sprouted the most $(78.2 \%)$, whereas it was lowest in 5-year-old donors $(56.7 \%)$. The results further showed that aging of donor plants significantly decreased number of leaves per SNC (Table 2). Significant interactions $(P \leq 0.05)$ between light condition and age of donor plants were observed for percent callusing, root length and number of roots per SNC (data not shown).

\section{Discussion}

The present study showed that aging and stock-plant etiolation caused a decrease in callus formation at the base of coppice-shoot cuttings. Previous studies have shown that a reduction in callus formation is beneficial for rooting by shoot cuttings $[7,8]$ because increased callusing has been observed to be associated with unfavorable auxin-nutrient (sugar) balance in meristematic cells in the rooting zone $[8,22,23]$. Single-node leafy coppice-shoot

Table 1. Effect of etiolation on root and shoot parameters of coppice-shoot single node cuttings from Tectona grandis seedlings.

\begin{tabular}{|c|c|c|c|c|c|c|c|c|}
\hline \multirow{2}{*}{ Light condition $^{\mathrm{a}}$} & \multicolumn{8}{|c|}{ Rooting parameters } \\
\hline & $\%$ callusing $^{\mathrm{b}}$ & $\%$ rooting $^{\mathrm{b}}$ & $\%$ sprouting $^{\mathrm{b}}$ & Shoots/cutting & $\begin{array}{l}\text { Shoot length } \\
\quad(\mathrm{cm})\end{array}$ & Leaves/cutting & Roots/cutting & $\begin{array}{l}\text { Root length } \\
\quad(\mathrm{cm})\end{array}$ \\
\hline Control & $20.00(18.77)$ & $41.67(38.54)$ & $48.33(45.59)$ & 0.76 & 3.33 & 3.00 & 1.65 & 4.79 \\
\hline Etiolation & $6.67(7.05)$ & $71.67(63.16)$ & $73.33(66.50)$ & 1.00 & 4.27 & 3.60 & 3.50 & 6.98 \\
\hline LSD0.05 & $10.50 *$ & $13.33 *$ & $15.17 *$ & $0.12 *$ & $0.47 *$ & $0.31 *$ & $0.42 *$ & $0.96^{*}$ \\
\hline
\end{tabular}

${ }^{a}$ The stock plants represent the stumps with three basal nodes coppiced from 1-, 2-, 3-, 4- and 5-year-old donor plants; they were etiolated in the dark for 20 days, while the control stumps were maintained under natural light in an open environment; ${ }^{\mathrm{b}}$ Figures within parenthesis represent arc sin square root transformed values; * = significantly different from the control at $P \leq 0.05$, according to $F$-test.

Table 2. Effect of aging on root and shoot parameters of coppice-shoot single node cuttings from Tectona grandis seedlings.

\begin{tabular}{|c|c|c|c|c|c|c|c|c|}
\hline \multirow{2}{*}{$\begin{array}{c}\text { Age of } \\
\text { donor plants }\end{array}$} & \multicolumn{8}{|c|}{ Rooting parameters } \\
\hline & $\%$ callusing ${ }^{a}$ & $\%$ rooting $^{\mathrm{a}}$ & $\%$ sprouting $^{\mathrm{a}}$ & Shoots/ cutting & $\begin{array}{l}\text { Shoot length } \\
\quad(\mathrm{cm})\end{array}$ & Leaves/ cutting & Roots/ cutting & $\begin{array}{l}\text { Root length } \\
\quad(\mathrm{cm})\end{array}$ \\
\hline 1 -year & $0.00(1.28)$ & $78.16(71.24)$ & $78.16(71.24)$ & 1.00 & 3.60 & 5.12 & 2.96 & 7.16 \\
\hline 2-year & $0.00(1.28))$ & $73.33(66.50)$ & $73.33(66.50$ & 1.00 & 3.63 & 5.00 & 2.90 & 7.00 \\
\hline 3-year & $0.00(1.28)$ & $70.00(61.40)$ & $70.00(61.40)$ & 1.00 & 3.54 & 3.60 & 2.80 & 6.54 \\
\hline 4-year & $3.32(3.52)$ & $63.33(53.03)$ & $66.67(58.51)$ & 1.00 & 3.46 & 2.40 & 2.70 & 6.11 \\
\hline 5 -year & $10.00(10.57)$ & $53.33(48.51)$ & $56.67(52.03)$ & 0.90 & 3.42 & 2.20 & 1.90 & 4.69 \\
\hline LSD0.05 & $7.80^{*}$ & $18.85^{*}$ & $18.01 *$ & ns & ns & $0.81 *$ & $0.59 *$ & $1.36^{*}$ \\
\hline
\end{tabular}

${ }^{\mathrm{a}}$ Figures within parenthesis represent arc sin square root transformed values; $*$ = significantly different from the control at $P \leq 0.05$, according to $F$-test; ns $=$ non-significant at $P \leq 0.05$, according to $F$-test. 
cuttings obtained from etiolated stock plants rooted and produced the most shoots. However, coppice-shoot cuttings obtained from non-etiolated stock plants formed roots and shoots, $41 \%$ and $48 \%$, respectively. The enhanced rooting efficiency is probably due to high sugar content in etiolated coppice-shoot cuttings, and possibly due to increased mobilization of carbohydrates from starch $[18,19]$. These changes might be beneficial for adventitious root primordium development in shoot cuttings. Sugar content was previously found to be positively correlated with rooting efficiency of teak cuttings $[12,18,23,24]$. An increase in sugar content of etiolated shoot cuttings was associated with profuse rooting [18, 22-24]. In addition, specific classes of flavonoid compounds may act as an auxin transport inhibitors [25]. Flavonoid biosynthesis is regulated by light. Although flavonoids are not accumulated in dark-grown seedlings, they are rapidly produced in response to light [26]. In the coppice-shoot cuttings of etiolated stock plants, the highest rooting response and shoot growth may perhaps be due to an inhibition of flavonoid biosynthesis. Furthermore, anthraquinones were established as a reliable marker for juvenility and maturity in teak $[18,23]$. Anthraquinones in coppice shoots obtained from etiolated and non-etiolated stock plants showed that etiolation restored some chemical features of juvenile shoots associated with enhanced rooting $[18,23]$. Similarly, in the present study coppice-shoot cuttings obtained from the etiolated stock plants have shown enhanced rooting, indicating that etiolation caused juvenility in teak. Overall, the beneficial effects of etiolation on rooting and shoot growth were reported in a number of taxa including teak $[10,15,18-21]$. In this study, both rooting and sprouting by coppice-shoot cuttings declined with increasing age of donor plants. Decreased rooting potential of cuttings due to aging/or maturity of donor plants has been previously reported in several plant species [6-8,10,28-30] which may be due to decreased sensitivity of aging tissues to rooting promoters or accumulation of inhibitory substances for rooting and/or decrease in the content of endogenous auxins responsible for root formation by cuttings [7,8,31]. In conclusion, the studies hitherto made to examine rooting response of etiolated vis-à-vis non-etiolated teak cuttings from coppice-shoot obtained from 1-, 2-, 3-, 4-, and 5-year-old donors. Stock-plant etiolation treatment increased rooting performance in coppice shoot cuttings of all age groups of donor plants, and etiolation treatment appears to rejuvenate teak stock plant, resulting in profuse rooting response.

\section{Acknowledgements}

This work was supported by World Bank Forest Re- search Education and Extension Programme (FREEP) and Indian Council of Forestry Research and Education (ICFRE), Dehra Dun, India.

\section{REFERENCES}

[1] D. Pandey and C. Brown, "Teak: A Global Overview," Unasylva, Vol. 51, No. 201, 2000. pp. 3-12.

[2] D. N. Tewari, "A Monograph on Teak (Tectona grandis Linn. f.)," International Book Distributors, Dehra Dun, 1992.

[3] E. P. Indira, S. Chand Basha and K. C. Chacko, "Effect of Seed Size Grading on the Germination and Growth of Teak (Tectona grandis) Seedling," Journal of Tropical Forest Science, Vol. 12, No. 1, 2000, pp. 21-27.

[4] M. Pal, "Vegetative Propagation of Teak by Rooting Stem Cuttings," Proceedings of Second Forestry Conference, Vol. 2, 1992, pp. 145-148.

[5] W. P. Hackett and J. R. Murray, "Maturation and Rejuvenation in Woody Species," In: M. R. Ahuja, Ed., Micropropagation of Woody Plants, Kluwer Academics Publishers, Dordrecht, 1993, pp. 93-105.

[6] M. S. Greenwood, C. Díaz-sala, P. B. Singer, A. Decker and K. W. Hutchison, "Differential Gene Expression during Maturation-Caused Decline in Adventitious Rooting Ability in Loblolly Pine (Pinus taeda L.)," In: A. Altman and Y. Weisel, Eds., Biology of Adventitious Root Formation and Development, Plenum Press, New York, 1997, pp. 203-208. doi:10.1007/978-1-4615-5403-5 37

[7] A. Husen and M. Pal, "Variation in Shoot Anatomy and Rooting Behaviour of Stem Cuttings in Relation to Age of Donor Plants in Teak (Tectona grandis Linn. f.)," New Forests, Vol. 31, No. 1, 2006, pp. 57-73. doi:10.1007/s11056-004-6794-5

[8] A. Husen and M. Pal, "Metabolic Changes during Adventitious Root Primordium Development in Tectona grandis Linn. f. (Teak) Cuttings as Affected by Age of Donor Plants and Auxin (IBA and NAA) Treatment," New Forests, Vol. 33, No. 3, 2007, pp. 309-323. doi:10.1007/s11056-006-9030-7

[9] R. R. B. Leakey, "Capacity for Vegetative Propagation in Trees," In: M. G. R. Cannel and J. Jackson, Eds., Attributes of Trees as Crop Plants, Institute of Terrestrial Ecology, Huntingdon, 1985, pp. 110-133.

[10] A. Husen and M. Pal, "Effect of Serial Bud Grafting and Etiolation on Rejuvenation and Rooting Cuttings of Mature Trees of Tectona grandis Linn. f.," Silvae Genetica, Vol. 52, No. 2, 2003, pp. 84-87.

[11] A. Husen and M. Pal, "Clonal Propagation of Teak (Tectona grandis Linn. f.): Effect of IBA Application and Adventitious Root Regeneration on Vertically Split Cuttings," Silvae Genetica, Vol. 52, No. 3-4, 2003, pp. 173-176.

[12] A. Husen and M. Pal, "Seasonal Changes in Rooting Response of Hardwood Cuttings of Teak (Tectona grandis Linn. f.) in Relation to Drift of Total Soluble Sugar, 
Starch and Total Nitrogen," Annals of Forestry, Vol. 15, 2007, pp. 11-31.

[13] A. Husen and M. Pal, "Effect of Branch Position and Auxin Treatment on Clonal Propagation of Tectona grandis Linn. f," New Forests, Vol. 34, No. 3, 2007, pp. 223-233. doi:10.1007/s11056-007-9050-y

[14] J. Ludwig-Müller, A. Vertocnik and C. D. Town, “Analysis of Indole-3-Butyric Acid-Induced Adventitious Root Formation on Arabidopsis Stem Segments," Journal of Experimental Botany, Vol. 56, No. 418, 2005, pp. 20952105. doi: $10.1093 / \mathrm{jxb} / \mathrm{eri} 208$

[15] C. Sorin, D. B. John, I. Camus, K. Ljung, M. Kowalczyk, G. Geiss, H. Mckhann, C. Garcion, H. Vaucheret, G. Sandberg and C. Bellini, "Auxin and Light Control of Adventitious Rooting in Arabidopsis Require ARGONAUTE1," Plant Cell, Vol. 17, No. 5, 2005, pp. 1-17. doi:10.1105/tpc. 105.031625

[16] A. Husen, "Clonal Propagation of Dalbergia sissoo Roxb. by Softwood Nodal Cuttings: Effects of Genotypes, Application of IBA and Position of Cuttings on Shoots," Silvae Genetica, Vol. 53, No. 2, 2004, pp. 50-55.

[17] A. Husen, "Clonal Propagation of Dalbergia sissoo Roxb. and Associated Metabolic Changes during Adventitious Root Primordium Development," New Forests, Vol. 36, No. 1, 2008, pp. 13-27. doi:10.1007/s11056-007-9079-y

[18] A. Husen, "Stock-Plant Etiolation Causes Drifts in Total Soluble Sugars and Anthraquinones, and Promotes Adventitious Root Formation in Teak (Tectona grandis L. f.) Coppice Shoots," Plant Growth Regulation, Vol. 54, No. 1, 2008, pp. 13-21. doi:10.1007/s10725-007-9222-y

[19] B. K. Maynard and N. L. Bassuk, "Etiolation and Banding Effects on Adventitious Root Formation" In: T. D. Davis, B. E. Haissig and N. Sankhla, Eds., Adventitious Root Formation by Cuttings, Dioscorides Press, Portland, 1988, pp. 29-46.

[20] B. K. Maynard and N. L. Bassuk, "Effect of Stock Plant Etiolation, Shading, Banding, and Shoot Development on Histology and Cutting Propagation of Carpinus betulus L Fastigata," Journal of the American Society for Horticultural Science, Vol. 121, No. 5, 1996, pp. 853-860.

[21] B. E. Haissig and T. D. Davis, "A Historical Evaluation of Adventitious Rooting Research to 1993," In: T. D. Davis and B. E. Haissig, Eds., Biology of Adventitious Root Formation, Plenum Press, New York, 1994, pp. 275-331.

[22] M. Pal, "Physiological and Biochemical Effects of Seasonal Changes in Stem Cuttings in Relation to Rooting," PhD Dissertation, Punjab University, Chandigarh, 1978.
[23] A. Husen, "Physiological Effects of Phytohormones and Mineral Nutrients on Adventitious Root Formation and Clonal Propagation of Tectona grandis Linn. f.," PhD Dissertation, Forest Research Institute, Dehra Dun, 2002.

[24] B. E. Haissig, "Reduced Irradiance and Applied Auxin Influence Carbohydrate Relation in Pinus banksiana Cuttings during Propagation," Physiologia Plantarum, Vol. 78, No. 3, 1990, pp. 455-461. doi:10.1111/j.1399-3054.1990.tb09063.x

[25] D. E. Brown, A. M. Rashotte, A. S. Murphy, J. Normanly, B. W. Tague, W. A. Peer, L, Taiz and G. K. Muday, "Flavonoids Act as Negative Regulators of Auxin Transport in Vivo in Arabidopsis," Plant Physiology, Vol. 126, No. 2, 2001, pp. 524-535. doi:10.1104/pp.126.2.524

[26] C. S. Buer and G. K. Muday, "The Transparent Testa4 Mutation Prevents Flavonoid Synthesis and Alters Auxin Transport and the Response of Arabidopsis Roots to Gravity and Light," Plant Cell, Vol. 16, No. 5, 2004, pp. 1191-1205. doi:10.1105/tpc.020313

[27] R. R. B. Leakey and R. Sstoreton-West, "The Rooting Ability of Triplochiton scleroxylon Cuttings: The Interactions between Stock Plant Irradiance, Light Quality and Nutrients," Forest Ecology and Management, Vol. 49, No. 1-2, 1992, pp. 133-150. doi:10.1016/0378-1127(92)90166-7

[28] C. Díaz-sala, G. Garrido and B. Sabater, "Age-Related Loss of Rooting Capability in Arabidopsis thaliana and Its Reversal by Peptides Containing the Arg-Gly-Asp (RGD) Motif," Physiologia Plantarum, Vol. 114, No. 4, 2002, pp. 601-607. doi:10.1034/j.1399-3054.2002.1140414.x

[29] G. Osterc, M. Štefančič, and F. Štampar, "Juvenile Stock Plant Material Enhances Root Development through Higher Endogenous Auxin Level," Acta Physiologiae Plantarum, Vol. 31, No. 5, 2009, pp. 899-903. doi:10.1007/s11738-009-0303-6

[30] E. Amri, H. V. B. Lyaruu, A. S. Nyomora and Z. L. Kanyelka, "Vegetative Propagation of African Blackwood (Dalbergia melanoxylon Guill. \& Perr.): Effects of Age on Donor Plant, IBA Treatment and Cutting Position on Rooting Ability of Stem Cuttings," New Forests, Vol. 39 No. 2, 2010, pp. 183-194. doi:10.1007/s11056-009-9163-6

[31] M. S. Greenwood, X. Cui and F. Xu, "Response to Auxin Changes during Maturation-Related Loss of Adventitious Rooting Competence in Loblolly Pine (Pinus taeda) stem Cuttings," Physiologia Plantarum, Vol. 111, No. 3, 2001, pp. 373-380. doi:10.1034/j.1399-3054.2001.1110315.x 